\title{
ANALGESIC EFFICACY OF EPIDURAL MORPHINE AND CLONIDINE IN PATIENTS UNDERGOING DECOMPRESSION OF THE LUMBAR CANAL: A PROSPECTIVE RANDOMIZED TRIAL
}

\author{
EFICÁCIA ANALGÉSICA DE MORFINA E CLONIDINA EPIDURAL EM PACIENTES SUBMETIDOS \\ À DESCOMPRESSÃO DO CANAL LOMBAR: ESTUDO PROSPECTIVO E RANDOMIZADO \\ EFICACIA ANALGÉSICA DE LA MORFINA Y CLONIDINA EPIDURAL EN PACIENTES SOMETIDOS \\ A DESCOMPRESIÓN DEL CANAL LUMBAR: ESTUDIO PROSPECTIVO ALEATORIZADO
}

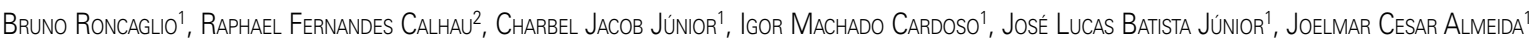

1. Hospital Santa Casa de Misericórdia de Vitoria, Spine Surgery Group, Vitória, ES, Brazil.

2. Santa Casa de Misericórdia de Vitoria, Escola Superior de Ciências, Vitória, ES, Brazil.

\begin{abstract}
Objective: To evaluate the postoperative analgesic efficacy in patients undergoing lumbar canal decompression using epidural morphine and clonidine at the Hospital Santa Casa de Vitória - ES, Brazil. Methods: Prospective, randomized study of 60 patients with stenosis of the lumbar canal up to two levels with surgical indication, in which decompression of the canal was performed in association with lumbar arthrodesis. In group 1 we performed conventional postoperative analgesia and in group 2 , in addition to conventional analgesia, we associated epidural morphine and clonidine. We used VAS as a means of analyzing pain intensity at 1, 12, and 36 hours after surgery. The statistical analysis was performed using Microsoft Office/Excel and the software GraphPad Prism (San Diego, CA, USA). Results: The mean age of patients was 47 years, and $52 \%$ were female. The mean VAS in the first hour, 12th, and 36th hours after surgery in the control group was $5.44,2.13$, and 0.55 respectively. In the morphine-clonidine group it was 6.96; 2.21 and 0.60 . Comparing one group with another in its absolute values through the Mann-Whitney test, as well as comparing the pain variations between the 1st and 12th hour (1h X 12h) and between the 12th hour and 36th hour (12h $\times 36 \mathrm{~h}$ ) through Student's t test it became clear that there was no statistical difference between groups $(p>0.05)$. Conclusions: The addition of epidural morphine and clonidine to conventional analgesia is not beneficial to reduce postoperative pain in patients undergoing lumbar canal decompression.
\end{abstract}

Keywords: Lumbar vertebrae; Analgesia, epidural; Morphine; Clonidine; Visual analog scale; Postoperative period.

\section{RESUMO}

Objetivo: Avaliar a eficácia analgésica pós-operatória em pacientes submetidos à descompressão do canal lombar utilizando morfina e clonidina epidural no Hospital da Santa Casa de Vitória - ES. Métodos: Estudo prospectivo, randomizado de 60 pacientes com de estenose do canal lombar até dois níveis, com indicação cirúrgica, na qual foi realizada descompressão do canal associada à artrodese lombar. No grupo 1, realizamos analgesia pós-operatória convencional e no grupo 2, além da analgesia convencional, associamos morfina e clonidina epidural. Utilizamos a EVA como forma de análise da intensidade da dor nos períodos de 1, 12 e 36 horas depois da cirurgia. A análise estatística dos dados foi realizada com Microsoft Office/Excel e o software GraphPad Prism (San Diego, CA, EUA). Resultados: A média da idade dos pacientes foi de 47 anos, sendo que 52\% eram do sexo feminino. A média da EVA na $1^{a}$, $12^{a}$ e $36^{a}$ horas depois da cirurgia no grupo controle foi de 5,44; 2,13 e 0,55, respectivamente. No grupo morfina-clonidina foi de 6,96; 2,21 e 0,60. Comparando um grupo com outro em seus valores absolutos através do teste Mann-Whitney, como também comparando as variações do quadro álgico entre a primeira e a décima segunda hora (1h X 12h) e entre a décima segunda hora e a trigésima sexta hora (12h X $36 h)$ através do teste $t$ de Student, evidenciou-se que não houve diferença estatística entre os grupos ( $p>0,05)$. Conclusões: A adição de morfina e clonidina epidural à analgesia convencional não é benéfica para reduzir o quadro álgico em pós-operatório de pacientes submetidos à descompressão de canal lombar.

Descritores: Vértebras lombares; Analgesia epidural; Morfina; Clonidina; Escala visual analógica; Período pós-operatório.

\section{RESUMEN}

Objetivo: Evaluar la eficacia analgésica postoperatoria en pacientes sometidos a la descompresión del canal lumbar utilizando morfina y clonidina epidural en el Hospital Santa Casa de Vitória - ES, Brasil. Métodos: Estudio prospectivo, aleatorizado de 60 pacientes con estenosis del canal lumbar hasta dos niveles, con indicación quirúrgica, en el cual se realizó descompresión del canal asociada a la artrodesis lumbar. En el grupo 1, realizamos analgesia postoperatoria convencional y en el grupo 2, además de la analgesia convencional, asociamos morfina y clonidina epidural. Utilizamos la EVA como forma de análisis de la intensidad del dolor en los períodos de 1, 12 y 36 horas después de la cirugía. El análisis estadístico de los datos se realizó con Microsoft Office/Excel y el software GraphPad Prism (San Diego, CA, EE. UU.).

Study developed at the Escola Superior de Ciências da Santa Casa de Misericórdia de Vitoria, Vitória, ES, Brazil.

Correspondence: Charbel Jacob Junior. Rua Doutor João Santos Neves, 143, Vila Rubim, Vitória, ES, Brasil. 29018-180. jcharbel@gmail.com 
Resultados: La edad media de los pacientes fue de 47 años, siendo que el 52\% eran del sexo femenino. La media de la EVA en la $1^{a}$, $12^{a}$ y $36^{a}$ horas después de la intervención en el grupo control fue de 5,44; 2,13 y 0,55, respectivamente. En el grupo morfina-clonidina fue de 6,96; 2,21 y 0,60. La comparación de un grupo con otro en sus valores absolutos a través de la prueba de Mann-Whitney, como también comparando las variaciones del cuadro de dolor entre la primera y la décima segunda hora (1h X $12 \mathrm{~h}$ ) y entre la décima segunda hora y la trigésima sexta hora (12h X 36h) por la prueba t de Student, se evidenció que no hubo diferencia estadística entre los grupos ( $p$ > 0,05). Conclusiones: La adición de morfina y clonidina epidural para analgesia convencional no es beneficiosa para reducir el cuadro de dolor en el postoperatorio de pacientes sometidos a la descompresión de canal lumbar.

Descriptores: Vértebras lumbares; Analgesia epidural; Morfina; Clonidina; Escala visual analógica; Periodo posoperatorio.

\section{INTRODUCTION}

Degenerative lumbar stenosis is characterized by narrowing of the spinal canal causing confinement of the neural structures from changes in the bones and adjacent soft tissues. It is one of the main causes of pain and loss of quality of life in the elderly population., In most cases, the treatment consists of analgesia, physical therapy, and functional rehabilitation. Several studies in the literature show progressive improvement in 15 to $43 \%$ of the patients during a follow-up of 1 to 5 years. ${ }^{1}$ When conservative treatment fails, a surgical procedure is appropriate. ${ }^{2,3}$ The objective of this treatment is the decompression of the vertebral canal and, according to the need, local stabilization to relieve the symptoms and control the pathology. ${ }^{2}$

Lumbar decompression associated with arthrodesis is an invasive surgery generating intense pain in the immediate post-operative period (IPO) and this can be related to an increase in morbidity and complications. Therefore, immediate care is of utmost importance in spine surgery and several studies address the improvement of post-operative analgesia following decompression of the lumbar canal. ${ }^{3}$ Many drugs are studied in this context and help to better understand effective pain reduction. One of the most used is intrathecal morphine, presenting satisfactory results in various studies, such as benefits in controlling the pain of oncological patients, ${ }^{4}$ promotion of analgesia with continuous infusion in patients with intractable pain, and reduction of pain following spinal fusion surgery. 5,6 However, intrathecal infusions require continuous monitoring and the use of morphine can cause some adverse effects such as urinary retention and respiratory depression, in addition to the possibility of the development of fistulae. ${ }^{7}$ The administration of epidural morphine in combination with clonidine is proposed in order to reduce the dose and thus minimize adverse effects like respiratory depression. ${ }^{8}$ Clonidine is an adrenergic agonist that acts directly on the adrenergic receptor $\alpha 2$, historically prescribed as an anti-hypertensive agent. The main adverse effects of this medication when used orally are dizziness, nausea, and hypotension, and the main ones related to parenteral use are skin eruptions, drowsiness, headache, and dry mouth. ${ }^{8}$ However, clonidine has been used in surgeries in combination with other drugs for analgesic control, as reported in the study by Kamble et al., in which the addition of clonidine as an adjuvant to bupivacaine improved the quality of the paravertebral block in patients who had undergone percutaneous nephrolithotomy, and it provided significantly better postoperative analgesia. ${ }^{9}$ In a study of analgesia in spine surgery, it was observed that peridural administration of morphine-clonidine significantly improved postoperative pain relief and reduced the consumption of opioid analgesics as compared to peridural bupivacaine-clonidine. ${ }^{10}$

\section{METHODS}

This was a prospective, randomized, double-blind study, conducted after approval by the Institutional Review Board as no. 12039913.1.0000.5065 and receipt of informed consent from all patients. Sixty randomized patients were evaluated, separated by simple lottery into two groups of 30 patients each. The data collection period was from May 2013, to April 2014.

The inclusion criteria were patients of both sexes with stenosis of the lumbar canal of degenerative etiology indicated for surgery of up to two levels, where all patients had undergone the same surgical technique for decompression of the lumbar canal followed by arthrodesis using pedicle screws and interbody device (cage).

The exclusion criteria considered were patients with allergies to any of the components of conventional analgesia, patients who underwent lumbar decompression surgery for causes other than degenerative changes of the lumbar spine, complications during the surgical procedure such as lesions of the dura mater, improper placement of the pedicle screws requiring replacement, patients with polyneuropathies, sensory and cognitive disorders.

A convenience sample of 60 patients was selected, based on previous similar studies, $5,6,8-1052 \%$ of whom were females with an average of 47 years of age, with no significant difference in the demographic data between the groups and the same proportion of one- and two-level surgeries between the groups.

The anesthetic procedure was conducted according to the standard protocol of the institution, which consists of an induction phase with fentanyl $5 \mu \mathrm{g} / \mathrm{Kg}$, atracurium $0.5 \mu \mathrm{g} / \mathrm{Kg}$, propofol $2 \mu \mathrm{g} / \mathrm{Kg}$, and midazolam $5 \mathrm{mg}$; a maintenance phase with isoflurane $1.5 \%$, atracurium $0.16 \mathrm{mg} / \mathrm{Kg} / \mathrm{h}$, fentanyl $50 \mu \mathrm{g}$ in case of intraoperative pain, and etilefrine $200 \mathrm{mg}$ for hypotension; an emergence phase with prostigmin $30 \mu \mathrm{g} / \mathrm{Kg}$ and atropine $15 \mu \mathrm{g} / \mathrm{Kg}$; in addition to postoperative analgesia with dipyrone $1 \mathrm{~g} \mathrm{IV} \mathrm{4/4} \mathrm{hours,} \mathrm{ketoprofen} 100 \mathrm{mg}$ IV 12/12 hours and tramadol $100 \mathrm{mg}$ IV 6/6 hours.

Group 1 (control group) received only conventional analgesia. Group 2 (study group: morphine-clonidine) in addition to the above-mentioned analgesia also received intraoperative analgesia consisting of morphine $1 \mathrm{mg}$ in combination with clonidine $75 \mu \mathrm{g}$.

After the surgical procedure, the visual analog scale (VAS) protocol was applied at 1, 12, and 36 hours following extubation in all patients included according to the selection criteria. In addition, any complications and any use of complementary analgesics were recorded (annex 1). Preoperative pain was not measured because the objective of the study was to evaluate and compare the postoperative pain of the different groups.

Friedman, Wilcoxon, and Mann-Whitney were used as non-parametric tests and the Student's t-test was used as the parametric test. The Friedman and Wilcoxon tests compared the analgesic efficiency of each group separately using the VAS taken at 1, 12, and 36 hours following extubation. The Mann-Whitney test compared the absolute VAS values between the groups and the Student t-test was used to compare the differences in the VAS between the groups at each time point.

The results were presented numerically as average values \pm standard deviation and some values were also expressed as percentages. Values with $p<0.05$ were considered to be statistically significant. The statistical data analysis was performed using Microsoft Office Excel and GraphPad Prism (San Diego, CA, USA) software.

\section{RESULTS}

A total of 60 patients, $52 \%$ of them female, were evaluated. No PO complications related to analgesia were recorded for any patient. In the control group, in which only conventional analgesia was administered, average VAS scores of $5.4483(\sigma=2.93), 2.1379$ $(\sigma=2.32)$, and $0.5517(\sigma=1.70)$ were observed at 1,12 , and 36 hours post-extubation, respectively, as displayed in Table 1.

In the study group where conventional analgesia combined with morphine and clonidine was administered, the average VAS scores 
observed were $6.9643(\sigma=1.64), 2.2143(\sigma=2.32)$, and 0.6071 $(\sigma=1.31)$ at 1,12 , and 36 hours, respectively, as displayed in Table 2 .

The Friedman test was used to compare the pain intensity of the three time points in each group. In the analysis of the VAS at the different time points researched ( 1 hour, 12 hours, and 36 hours after extubation), we observed that both in the study group (morphine-clonidine) and the control group there were significant differences among the distributions of pain at the three time points $(p<0.05)$. Comparing the intensity of the pain at one time point with that at the subsequent time point using the Wilcoxon test, it was confirmed that in both the morphine-clonidine group and in the control group there were significant differences ( $p$ $<0.05$ ) among the distributions of pain, i.e., the intensity of the pain diminishes over time, according to Tables 3 and 4.

In addition, a comparison between the two groups using the Mann-Whitney test, as displayed in Table 5 below, shows that there is no significant difference in pain intensity between the morphine-clonidine group and the control group at one, twelve, and thirty-six hours.

The difference between the pain levels (from one hour to 12 hours and from 12 hours to 36 hours) presented a normal probability distribution both in the control and study groups, with significances greater than $5 \%$. Thus, the comparison of these differences using the Student's t-test for independent samples was justified.

Considering the absolute values of the differences between the pain levels, the average of the difference between one and twelve hours in the morphine group was 4.73, while in the control group it was 3.87. The averages of the differences between 12 and 36 hours were practically equal for both groups: 1.68 for the morphine group and 1.66 for the control group (Table 6).

Using the Student's t-test for the comparison of independent samples, we verified that the reduction in the pain level did not differ significantly between the morphine-clonidine and control groups, either for the period between one and twelve hours or for the period between twelve and thirty-six hours, with levels of significance greater than 0.05, as per Table 7 .

Table 1. Average VAS 1, 12, and 36 hours following the extubation of patients with conventional analgesia

\begin{tabular}{c|c|c|c}
\hline Hours & $\mathbf{N}$ & Averages & $\begin{array}{c}\text { Standard } \\
\text { Deviation }(\boldsymbol{\sigma})\end{array}$ \\
\hline One hour (1 h) & 30 & 5.4483 & 2.93484 \\
\hline Twelve hours (12 h) & 30 & 2.1379 & 2.32570 \\
\hline Thirty-six hours (36 h) & 30 & 0.5517 & 1.70265 \\
\hline
\end{tabular}

Table 2. Average VAS 1, 12, and 36 hours following the extubation of patients with conventional analgesia associated with epidural morphine and clonidine.

\begin{tabular}{c|c|c|c}
\hline Hours & $\mathbf{N}$ & Averages & $\begin{array}{c}\text { Standard } \\
\text { Deviation }(\boldsymbol{\sigma})\end{array}$ \\
\hline One hour $(1 \mathrm{~h})$ & 30 & 6.9643 & 1.64389 \\
\hline Twelve hours $(12 \mathrm{~h})$ & 30 & 2.2143 & 1.98806 \\
\hline Thirty-six hours $(36 \mathrm{~h})$ & 30 & 0.6071 & 1.31485 \\
\hline
\end{tabular}

Table 3. Comparison of VAS scores between the first and 12th and between the 12th and 36th hour after extubation in patients with conventional analgesia.

\begin{tabular}{c|c|c}
\hline & $\begin{array}{c}\text { One hour (1 } \mathbf{~ h ) ~ X} \\
\text { Twelve hours (12 } \mathbf{~})\end{array}$ & $\begin{array}{c}\text { Twelve hours (12 h) X } \\
\text { Thirty-six hours (36 h) }\end{array}$ \\
\hline Average & $5.45 \times 2.14$ & $2.14 \times 0.55$ \\
\hline Significance & $p<0.001$ & $p<0.001$ \\
\hline
\end{tabular}

Table 4. Comparison of VAS scores between the first and 12th and the 12th and 36th hour following extubation in patients with conventional analgesia associated with epidural morphine-clonidine.

\begin{tabular}{c|c|c}
\hline & $\begin{array}{c}\text { One hour (1 } \mathbf{h}) \mathbf{X} \\
\text { Twelve hours (12 } \mathbf{~})\end{array}$ & $\begin{array}{c}\text { Twelve hours (12 h) X } \\
\text { Thirty-six hours (36 h) }\end{array}$ \\
\hline Average & $6.96 \times 2.21$ & $2.21 \times 0.61$ \\
\hline Significance & $p<0.001$ & $p<0.001$ \\
\hline
\end{tabular}

Table 5. Comparison between the morphine-clonidine group and the control group at 1,12 , and 36 hours.

\begin{tabular}{c|c|c|c}
\hline Morphine-clonidine & $\mathbf{1 ~ h}$ & $\mathbf{1 2} \mathbf{~ h}$ & $\mathbf{3 6} \mathbf{~ h}$ \\
\hline $\mathrm{X}$ Control & $6.96 \times 5.45$ & $2.21 \times 2.13$ & $0.61 \times 0.55$ \\
\hline Significance $(\mathrm{p})$ & 0.056 & 0.646 & 0.342 \\
\hline
\end{tabular}

Table 6. Differences in the absolute values of the VAS of the morphineclonidine group and the control group between the first and 12th hour and between the 12th and 36th hour following extubation.

\begin{tabular}{c|c|c|c|c}
\hline & Group & $\mathbf{N}$ & $\begin{array}{c}\text { Average of } \\
\text { differences }\end{array}$ & $\begin{array}{c}\text { Standard } \\
\text { Deviation }\end{array}$ \\
\hline $\begin{array}{c}\text { Difference } \\
\text { between the 1st } \\
\text { and 12th hour }\end{array}$ & Morphine/clonidine & 30 & 4.73 & 1.95 \\
\cline { 2 - 5 } $\begin{array}{c}\text { Difference } \\
\text { between the 12th } \\
\text { and 36th hour }\end{array}$ & Control & 30 & 3.87 & 2.33 \\
\cline { 2 - 5 } & Control & 30 & 1.66 & 1.94 \\
\hline
\end{tabular}

Table 7. Comparison of the average of the differences of the morphineclonidine and control between the first and 12th hour and the 12th and 36th hour following extubation.

\begin{tabular}{c|cccc|c}
\hline & $\begin{array}{c}\text { Morphine- } \\
\text { clonidine }\end{array}$ & Control & $\begin{array}{c}\text { Significance } \\
\text { (p) }\end{array}$ \\
\hline $\begin{array}{c}\text { Difference between the } \\
\text { 1st and 12th hour }\end{array}$ & 4.73 & $\times$ & 3.87 & 0.123 \\
\hline $\begin{array}{c}\text { Difference between the } \\
\text { 12th and 36th hour }\end{array}$ & 1.68 & $\times$ & 1.66 & 0.960 \\
\hline
\end{tabular}

In summary, each of the two groups considered alone presented a significant reduction in pain $(p<0.0001)$ as evidenced in Tables 3 and 4 , however, when the absolute values of the groups were compared using the Mann-Whitney test (Table 5) and when the variations in pain between the first and twelfth hour (1hX12h) and between the twelfth and thirty-sixth hour (12h X 36h) were compared using the Student's t-test (Table 7), no statistical difference was observed between the groups ( $p>0.05$ ), demonstrating that there is no benefit to adding epidural morphine and clonidine in the doses recommended for association with conventional analgesia in the management of pain following surgery for arthrodesis and lumbar compression. Moreover, there were no significant adverse effects related to the medications.

\section{DISCUSSION}

Pain is an unpleasant defense experience with chemical, physiological, and psychological consequences, very common in the IPO of arthrodesis and lumbar decompression. ${ }^{11}$ It is accompanied by hormonal, metabolic, and psychological responses to trauma that can have profound effects on the body, such as arrhythmias, hypertension, myocardial ischemia, tachypnea, delayed gastric emptying, in addition to delayed mobilization that can lead to pressure ulcers and thromboembolism. ${ }^{11,12}$ Around $33 \%$ of patients report having moderate pain and $10 \%$ are victims of intense pain following invasive surgery. ${ }^{11}$ Lack of pain control in the IPO can lead to serious and morbid consequences, or even cause death. ${ }^{12}$ Thus, pain management is extremely important and unlike other drugs, opioids are still the most potent analgesics for treating intense pain, morphine being the principal member of this class.

Studies with epidural analgesia following lumbar arthrodesis are important due to the numerous benefits of safe, effective, and quality analgesia. At the beginning of the 21 st century, the number of studies of this kind began to increase due to the need for rapid postoperative recovery with minimal adverse effects. A recent study showed the benefit of intraoperative epidural adjuvancy associated with general anesthesia as compared to only general anesthesia. ${ }^{10}$ Bonhomme et al. ${ }^{13}$ used identical concentrations of morphine and clonidine to those used in this study and observed an improvement in analgesia with low doses of peridural morphine associated with clonidine when compared to $12.5 \mathrm{mg}$ of bupivacaine and $75 \mu \mathrm{g}$ of clonidine. Another similar benefit of the study was the absence of the expected adverse effects associated with morphine, with the exception of urinary retention. ${ }^{13}$ 
Both drugs present significant adverse effects. The main ones related to parenteral clonidine are rashes, drowsiness, headache, and dry mouth. In epidural use, arterial and postural hypotension are prominent. ${ }^{13-15}$ Morphine has other more common effects such as pruritus, vomiting, constipation, urinary retention, and respiratory depression, the last two being more prevalent in epidural and particularly intrathecal use. These effects are directly related to the dose,${ }^{14}$ hence, the importance of low doses of opioids. In this study, the adverse effects were insignificant.

The analgesic synergy of the association of morphine with clonidine can be explained by the fact that their receptors ( $\mu$ opioid and $\alpha_{2 A}$ adrenergic) belong to the same family: Rhodopsin G-protein coupled receptors, with similar and crossed signal transduction pathways affecting the nociceptive system. ${ }^{15}$ In their study of the modulation of receptors, Jordam et al. ${ }^{15}$ demonstrated that the isolated activation of one or another receptor leads to an increase in the signaling of the pain, whereas the simultaneous activation of the $\mu$ opioid and $\alpha_{2 A}$ adrenergic receptors leads to a significant reduction in pain signaling. This corroborates the findings of various studies that indicate the use of small doses of drugs of varying classes, used to obtain maximum individual performance with a reduction in the occurrence of adverse effects. ${ }^{16-19}$

Farmey et al. ${ }^{20}$ observed a significant reduction in additional analgesic demand for morphine with the use of epidural clonidine, generating a relevant attenuation of its side effects. Therefore, the low dose of drugs when associated would explain the non-occurrence of the expected adverse effects such as nausea, vomiting, urinary retention, or even respiratory failure. However, this low dose of morphine may explain the fact that there was no analgesic difference, according to the VAS, between the study and control groups.

A retrospective study conducted in Taiwan with 165 patients selected from 580 patients in the postoperative period following lumbar surgery found that the use of $1 \mathrm{mg}$ of epidural morphine embedded in microfibrillar collagen without the association of clonidine produced collateral effects, the main ones being nausea, pruritus, and vomiting. ${ }^{21}$ In addition to these effects, the study also noted that there was no statistical difference between the group that used $1 \mathrm{mg}$ of epidural morphine and the control. ${ }^{21}$
A recent Brazilian study conducted at the Hospital Santa Tereza in Petrópolis-RJ evaluated 40 patients retrospectively and randomly. This study showed an improvement in pain according to the VAS when $2 \mathrm{mg}$ of epidural morphine was used, but the authors used one preoperative and one postoperative pain point in their analysis in these patients, not mentioning possible adverse effects. ${ }^{22}$

Our study demonstrated that there was no statistically significant relationship between the groups when applying $1 \mathrm{mg}$ of morphine associated with $75 \mu \mathrm{g}$ of epidural clonidine, according to the analyses of the VAS obtained between the 1st and 12th hour $(p=0.123)$ and between the 12th and the 36th hour $(p=0.960)$ following extubation in patients who underwent lumbar arthrodesis at one or two levels. This does not mean that the study group was not effective alone, i.e., the group submitted to epidural morphine and clonidine experienced analgesia of the same quality as that of the control group using conventional analgesia, as evidenced by the analysis of the pain points. However, when the comparing the pain between the groups in the first hour following extubation, a value of $p=0.056$ was calculated, which could have occurred because of the number of patients selected in each group, justifying further studies with larger samples.

The positive aspect was the non-occurrence of the potential adverse effects inherent in the use of epidural morphine or clonidine. This study has limitations, among them the fact that pain was not measured (VAS) in the preoperative period and so could not be compared with thee postoperative results and the small samples in each group. One of the major challenges of this line of research would be to optimize the exact dose of epidural morphine in favor of analgesic improvement with a minimum of adverse effects in a greater number of patients.

\section{CONCLUSION}

The association of clonidine with epidural morphine does not promote reduction of postoperative pain in patients submitted to decompression of the lumbar canal when compared to conventional analgesia.

All authors declare no potential conflict of interest related to this article.

CONTRIBUTION OF THE AUTHORS: Each author made significant individual contributions to this manuscript. BR and RFC began the research with a bibliographical survery and the initial preparation of the manuscript. CJJ, IMC, JLBJ, JCA and BR conducted patient selection conducting outpatient consultations and performing the surgical procedures. BR, RFC, and JLBJ evaluated the statistical analysis data, conducted the bibliographical research, and actively participated in the discussion of the data obtained. CJJ and IMC performed the final review, the approval of the manuscript, and they contributed to the concept of the study. All the authors followed-up with patients in the postoperative period and collected clinical data.

\section{REFERENCES}

1. Valesin Filho ES, Ueno FH, Cabral LTB, Yonezaki AM, Nicolau RJ, Rodrigues LMR. Estudo prospectivo de avaliação de dor e incapacidade de pacientes operados de estenose de canal lombar com seguimento mínimo de dois anos. Coluna/Columna. 2009;8(4):390-4.

2. Issack PS, Cunningham ME, Pumberger $M$, Hughes AP, Cammisa FP Jr. Degenerative lumbar spinal stenosis: evaluation and management. J Am Acad Orthop Surg. 2012;20(8):527-35.

3. Chan JH, Heilpern GN, Packham I, Trehan RK, Marsh GD, Knibb AA. A prospective randomized double-blind trial of the use of intrathecal fentanyl in patients undergoing lumbar spinal surgery. Spine (Phila Pa 1976). 2006;31(22):2529-33.

4. Shetter AG, Hadley MN, Wilkinson E. Administration of intraspinal morphine sulfate for the treatment of intractable cancer pain. Neurosurgery. 1986;18(6):740-7.

5. Follett KA, Hitchon PW, Piper J, Kumar V, Clamon G, Jones MP. Response of intractable pain to continuous intrathecal morphine: a retrospective study. Pain. 1992:49(1):21-5.

6. Blacklock JB, Rea GL, Maxwell RE. Intrathecal morphine during lumbar spine operation for postoperative pain control. Neurosurgery. 1986;18(3):341-4.

7. Ko S, Goldstein DH, VanDenKerkhof EG. Definitions of "respiratory depression" with intrathecal morphine postoperative analgesia: a review of the literature. Can J Anaesth. 2003;50(7):679-88

8. Boezaart AP, Eksteen JA, Spuy GV, Rossouw P, Knipe M. Intrathecal morphine. Double-blind evaluation of optimal dosage for analgesia after major lumbar spinal surgery. Spine (Phila Pa 1976). 1999;24(11):1131-7.

9. Kamble TS, Deshpande CM. Evaluation of the Efficacy of Bupivacaine $(0.5 \%)$ alone or with Clonidine $(1 \mu \mathrm{g} / \mathrm{kg})$ Versus Control in a Single Level Paravertebral Blockin Patients Undergoing PCNL Procedure. J Clin Diagn Res. 2016:10(12):UC13-UC17.

10. Khajavi MR, Asadian MA, Imani F, Etezadi F, Moharari RS, Amirjamshidi A. General anesthesia versus combined epidural/general anesthesia for elective lumbar spine disc surgery: A randomized clinical trial comparing the impact of the two methods upon the outcome variables. Surg Neurol Int. 2013:4:105

11. Cailliet R. Dor: mecanismos e tratamento. São Paulo: Artmed;1993.

12. Kopf A, Patel NB. Guia para o Tratamento da Dor em Contextos de Poucos Recursos. USA: IASP; 2010
13. Bonhomme V, Doll A, Dewandre PY, Brichant JF, Ghassempour K, Hans P. Epidural administration of low-dose morphine combined with clonidine for postoperative analgesia after lumbar disc surgery. J Neurosurg Anesthesiol. 2002:14(1):1-6.

14. Duarte LTD, Saraiva RA, Costa VV, Fernandes MCB. Incidência de depressão respiratória no pós-operatório em pacientes submetidos a analgesia venosa ou peridural com opióides. Rev Bras Anestesiol. 2009;59(4):409-20.

15. Jordan BA, Gomes I, Rios C, Filipovska J, Devi LA. Functional interactions between mu opioid and alpha 2A-adrenergic receptors. Mol Pharmacol. 2003;64(6):1317-24.

16. Lavand'homme PM, Roelants F, Waterloos H, Collet V, De Kock MF. An evaluation of the postoperative antihyperalgesic and analgesic effects of intrathecal clonidine administered during elective cesarean delivery. Anesth Analg. 2008:107(3):948-55.

17. Neves JF, Monteiro GA, Almeida JR, Sant'anna RS, Saldanha RM, Moraes JM, et al. Postoperative analgesia for cesarean section: does the addiction of clonidine to subarachnoid morphine improve the quality of the analgesia?. Rev Bras Anestesiol. 2006:56(4):370-6

18. Fonseca NM, Oliveira CA. Efeito da clonidina associada à bupivacaína a $0,5 \%$ hiperbárica na anestesia subaracnóidea. Rev Bras Anestesiol. 2001;51(6):483-92.

19. Sites $B D$, Beach $M$, Biggs $R$, Rohan $C$. Wiley $C$, Rassias A et al. Intrathecal clonidine added to a bupivacaine-morphine spinal anesthetic improves postoperative analgesia for total knee arthroplasty. Anesth Analg. 2003;96(4):1083-8.

20. Farmery AD, Wilson-MacDonald J. The analgesic effect of epidural clonidine after spinal surgery: a randomized placebo-controlled trial. Anesth Analg. 2009:108(2):631-4

21. Wu MH, Wong CH, Niu CC, Tsai TT, Chen LH, Chen WJ. A comparison of three types of postoperative pain control after posterior lumbar spinal surgery. Spine (Phila Pa 1976). 2011;36(25):2224-31.

22. Amaral CAB, Vieira T, Nakagawa ET, Losch EA, José LP. Nível de dor no pós-operatório imediato de artrodese lombar após infiltração epidural com sulfato de morfina. Rev Bras Ortop. 2015;50(1):72-6. 
Annex 1.

\section{Evaluation protocol - VAS}

A. Name:

B. Age:

C. Telephones:

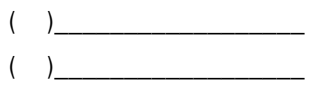

D. Sex:
1. ( ) Male
2. ( ) Female

E. last period: months ago

F. Weight:

G. Height:

H. BMI:

I. Diagnosis:

\section{Pre-operative questionnaire:}

J. Type of surgery: 1. ( ) 1 Level; 2. ( ) 2 Levels

K. Group: 1. ( ) Group 1; 2. ( ) Group 2

L. VAS: 1 hour PO ( ) VAS $(0-10)$

M. VAS: 12 hours PO ( ) VAS $(0-10)$

N. VAS: 36 hours PO ( ) VAS $(0-10)$

O. Complications
1. ( ) None
2. ( ) Nausea
3( ) Paraplegia

4. ( ) Urinary retention

5. ( ) Respiratory failure

6. ( ) Other

P. Infiltration of the skin
1. ( ) Yes
2. ( ) No
Q. Complementary analgesia

1. ( ) Tramadol 2.( ) Ketoprofen

Anesthesia protocol

A. Name:

Induction:

Fentanyl $\mu g(5 \mu g / K g)$

Atracurium $\mathrm{mg}(0.5 \mathrm{mg} / \mathrm{Kg})$

Propofol $\mathrm{mg}(2 \mathrm{mg} / \mathrm{Kg})$

Maintenance:

Isoflurane $\%(1.5 \%)$

Atracurium $\mathrm{mg}(0.16 \mathrm{mg} / \mathrm{Kg} / \mathrm{hour})$

Fentanyl $\mu \mathrm{g}(50 \mu \mathrm{g}$, in case of intraoperative pain)

Etilefrine $\mathrm{mg}(200 \mathrm{mg}$, in case of hypotension)
B. Weight:

\section{Emergence:}

Prostigmin $\mu \mathrm{g}(30 \mu \mathrm{g} / \mathrm{Kg})$

Atropine $\mu \mathrm{g}(15 \mu \mathrm{g} / \mathrm{Kg})$

Postoperative analgesia:

Dipyrone $2 \mathrm{~g}(\mathrm{)}$

Ketoprofen 100 mg ( ) 